\title{
A Critic and Suggestion to Turkey's Way of the Transition From Semi-periphery to Center: Role of Intellectual Capital
}

\author{
Erhan ATAY, Gökhan KARSAN \\ Süleyman Şah University, Istanbul, Turkey
}

\begin{abstract}
Because of Turkey's significant economic development since 1980s, politicians and public have very optimistic view on Turkey's political and economic rise and becoming regional powerhouse in the 21 st century. This view seems to be very optimistic. Historical heritage, success on international politics and having bounty of natural resources are significant success factors and these may lay the foundations for industrialization but these are not sufficient alone. Historically, Capitalist World-Economy founded on a horizontal division of labor. This international division of labor is dynamic, it is concerned a dynamic mobility — not too fast—among center, semi-periphery and periphery. Turkey has been striven in order to become an effective economic and political power both its own region and among other states. The meaning of this, according to Wallerstein, is that Turkey wants to transition from semi-periphery that it is included in the international division of labor to core/center region. It depends on its realize relatively monopolized or semi monopolized production process that is unique to center. Turkey has a positive brand image within EU, Middle East, and Central Asia markets. However, readiness for the strong economic structure needs qualified national intellectual capital. It will be very difficult for Turkey to be able to depend on cheap labor, traditional sources of production, and natural resources for competition. The rule of the economic competition and development is changing towards the creation of intellectual capital and establishing a national innovation system. This study aims to explore the position of Turkey on national intellectual capital formation with respect to and other Asian areas - China, India, South Korea, and Taiwan. It will be used various assessment criteria to examine whether Turkey is becoming a world leader or has a long way to go.
\end{abstract}

Keywords: Turkey, capitalist world-economy, international division of labor, national intellectual capital, national innovation system, China, India, South Korea, Taiwan

\section{Introduction and Problematic}

This study aims to inquire the determination on the Turkey's economy in the last 30 years: A specific development effort has continued since 1980 in Turkey. It cannot be said this effort is based on a rational and consistent development strategy. Moreover, except for ruling of "Anavatan Party" and "AdaletveKalkınma Party", nearly half of the last 30 years has been in political instability. Despite this, when Turkey's socio-economic status of especially last 10 years compared to both previous years and developing countries and

Erhan ATAY, Assistant Professor, Dr., Department of Business Administration, Faculty of Business and Management, Süleyman Şah University.

Gökhan KARSAN, Assistant Professor, Dr., Department of Political Science and Public Administration, Faculty of Business and Management, Süleyman Şah University.

Correspondence concerning this article should be addressed to Erhan ATAY, SüleymanŞah University, Istanbul, Turkey. E-mail: eatay@ssu.edu.tr. 
its near territory, it has been remarkably positive.

This positive picture is largely a result of socio-economic reforms. For example, populist policies on wages and employment (Eser \& Terzi, 2003, pp. 242-246; Çalış, 2011, pp. 307-322) have been largely abandoned. Tax evasion and smuggling (Çetintaş \& Vergil, 2003, pp. 15-30) have been largely tried to prevent. In order to support the manufacturing sector, interest and economic incentive policies (Acar \& Çağlar, 2012), and in order to increase exports, floating exchange rate and monetary policies (implicit and explicit inflation targeting strategies) (Kartal, 2011, pp. 77-100; Kaya, Akiş, \& Çağlar, 2011, pp. 69-103) were taken decision of principle. In order to struggle unemployment and illegal labor (Bekiroğlu, 2010), medium and long-term projects were designed. It can be seen that this reform and practices reflected in the growth rates. Turkey's economy has been growing steadily since 2002. In addition, various projects have been implemented in order to increase the level of individual and collective prosperity (Dinç, 2011, pp. 323-356). The reforms in health, education, transportation, insurance regime and directly or indirectly social aid channels are remarkable.

Turkey is striving for development for the last 30 years. Especially for the last 10 years, relatively stable political climate has been experienced. Turkey caught a stable growth trend. In terms of domestic policy, it has followed a policy which aimed at increasing socio-economic prosperity generating capacity of their institutions. In foreign policy, it has followed a policy that aimed at increasing its effectiveness and prestige in its region and in the world.

However, Turkey's projection for the year 2023 have been adopted as including in the world's most advanced 10 countries in this date which is corresponds to 100th anniversary of the proclamation of the Republic. The meaning of the 2023 projection and Turkey's economic development efforts and reforms which have continued for the last 30 years is - in the context of the historian Immanuel Wallerstein's world-systems theory - an attempt to pass from a semi-peripheral political unit to the central (core) states in the international division of labor of the capitalist world-economy.

At this point, the central issue of this study has crystallized: although Turkey achieved political stability, realized economic growth rates, put into practice socio-economic and administrative bureaucratic reforms, all this will not be enough for Turkey to carry from the semi-periphery to centre in the short and medium term.

It can be made two-dimensional discussion in order to support this idea. First, it is required to explain why the efforts that mentioned above efforts and positive statistical data will not be enough for Turkey's 2023 vision. For this purpose, it is necessary to make an inquiry on logic of the background of the functioning of the capitalist world-economy. Because, the emergence, rice and fall of the nation-states, political economy, and social class and ethnic or religious groupings are meaningful and understandable in the context of the capitalist world-economy. The capitalist world-economy creates - and is based on-both as a geographically and technologically a hierarchical division of labor. This division of labor can be called as the central government(s) and peripheral and semi-peripheral areas. The basic principle that distinguishes between central, periphery, and semi-periphery is skill in using relative advantage and superiority on production and, of course, marketing of goods that are more profitable and less "scarce" than other areas. This advantage and specialization can be raw materials, as well as products and services that are required advanced technology, specialization, and high organization.

This is exactly the second point of this discussion. The factor which will provide an advantage to a region or state compared with other regions in the 21 st century is national intellectual capital. It can be said that the realizing their transition of states or regions from the semi-periphery to the center in the international division 
of labor is possible by increasing the national intellectual capital and its ability level.

In this regard, discussion for the targets of year 2023 becomes possible via a specific policy: Turkey's current national intellectual capital capacity is not sufficient for the objectives of the year 2023. This point is the place to come together a critique and suggestion that can be done through the concept of national intellectual capital. In summary, although the current data and hopes for the future are quite promising, Turkey is not ready for the vision of year 2023 in terms of capacity and capability of national intellectual capital. Such a vision, however, can be realized as planned and determined effort and investment which aims to increase the capacity and capability of the national intellectual capital.

In this context, it is possible to make two-step discussion to prove the above hypothesis. In the first stage, it is necessary to make an investigation on logic of the background of the functioning of the capitalist world-economy. For this purpose, it may be functional to refer to Immanuel Wallerstein's world-system analysis in terms of this study. In the second stage, It will be discussed the concept of national intellectual capital. In this debate, the issue can be handled by using a comparative approach. For this purpose, some states which have made planned and stable investments in national intellectual capital will be examined and focus on common aspects. In the conclusion part, it will be examined the current ability and capacity of the Turkey's intellectual capital and will be presented a suggestion on its potential for the future.

\section{Capitalist World-Economy, International Division of Labour and Hegemony}

When it can be made reference to Wallerstein's historical sociology in order to question the logic of the functioning of the capitalist world economy, following four arguments that related to each other offer a way out. The first of these is linked to the specificity of capitalism as a system: What distinguishes the historical social system, which is called historical capitalism, is that in this historical system capital came to be used (invested) in a very special way (Wallerstein, 1999, pp. 13-14). It came to be used with the primary objective or intent of self-expansion. So, according to Wallerstein, what historical capitalism distinguishes from the earlier historical social systems is that: (1) each point of the chain of process (sometimes called circuit of capital) which composed of accumulation of capital, wage-labor, production processes, distribution processes, and marketing commodified enough; and (2) production processes which are including the social processes connected to each other as a complex commodification chains (Wallerstein, 1999, pp. 13-17; Wallerstein, 1993, p. 4). The genesis of these processes is located in late 15th century Europe, and these processes expanded in space to cover the entire globe by the late 19th century, and it still today covers the entire globe.

The second argument is distinction between the market economy and capitalism. Here, the historian Fernand Braudel inspires Wallerstein. Braudel mentions about daily market exchanges, what he means is an area that is regular, predictable, routine, and open to competition-namely, both large and small entrepreneur. There are no surprises in this area. It is quite "transparent" exchange area which each party already knows in advance the rules and outcome that they will obtain, and which they can roughly calculate beforehand moderate profits that they will earn (Braudel, 1977, p. 50).

The second category which Braudel portrayed is a specific market that tries to get rid of itself from the rules which traditional market (as described above) is imposed. This "sphere of circulation" which is also known as "anti-market" (Braudel would prefer to stress differences and call it the "countermarket") have explicitly acquired itself the ability to get rid of regulation and controls (Braudel, 1977, pp. 51-52). This type of exchange weakens something that can be considered most important rule of a market game, that is, competition, 
by cutting direct ties between buyers and sellers. As far as it can be understood that the examples given by Braudel, this anti-market increasingly grow rich thanks to speculations which is promising big profits (such as production or manufacturing cartels, smuggling, long-distance trade which turns direction to famine and disease areas) (Braudel, 1977, p. 52).

The third argument is about the basic unit of analysis that will be used to understand the historical capitalism, and it is inspired by Braudel's ideas: Braudel emphasized the issue of the unit of analysis. In his first major work, he insisted that the 16th century Mediterranean, which he was studying, constituted a "world-economy" (économie-monde), and he made the history of this world-economy the object of his study (Wallerstein, 2004, p. 15). Thus, rather than territorial political-economic unit, Braudel determines on a larger geographies which includes more than one politic-economic unit that located at different distances from each other as the basic unit of analysis which he uses to explain. Therefore, world-systems analysis meant the substitution of a unit of analysis called the "world-system" for the standard unit of analysis, which was the national state (Wallerstein, 2004, p. 16).

What Wallerstein (2004) means by a world-economy is:

A large geographic zone within which there is a division of labor and hence significant internal exchange of basic or essential goods as well as flows of capital and labor. A defining feature of a world-economy is that it is not bounded by a unitary political structure. Rather, there are many political units inside the world economy, loosely tied together in our modern world-system in an interstate system. And a world-economy contains many cultures and groups-practicing many religions, speaking many languages, differing in their everyday patterns. This does not mean that they do not evolve some common cultural patterns, what we shall be calling a geoculture. It does mean that neither political nor cultural homogeneity is to be expected or found in a world-economy. What unifies the structure most is the division of labor which is constituted within it. (p. 23)

Which this point is linked the remarkable fourth argument of Wallerstein's world-systems analysis.

According to Wallerstein, capitalist world-economy was said to be marked by an axial division of labor between core-like production processes and peripheral production processes, which resulted in an unequal exchange favoring those involved in core-like production processes (Wallerstein, 2004, p. 17; Wallerstein, 1974b, p. 391). This is the most crucial point of the issue. What makes a production process core-like or peripheral is the degree to which particular processes were relatively monopolized or relatively free market. The processes that were relatively monopolized were far more profitable than those that were free market. In this context, following quoted text is remarkable:

This made the countries in which more core-like processes located wealthier. And given the unequal power of monopolized products vis-à-vis products with many producers in the market, the ultimate result of exchange between core and peripheral products was a flow of surplus-value (meaning here a large part of the real profits from multiple local productions) to those states that had a large number of core-like processes. (Wallerstein, 2004, p. 18)

What determines hierarchy and mobility in the division of labor among regions — center/semi-periphery/periphery—is relatively monopolized production process, which required technology, specialization, and organizational skills. What is important here is that, in a conjuncture that includes favorable conditions, a region that had small advantage converts to the region that had big difference. In other words, particular regions of the world may change their structural role in the world-economy, to their advantage even though the disparity of reward between different sectors of the world-economy as a whole may be simultaneously widening (Wallerstein, 1974a, p. 350). According to Wallerstein, for example, in the 16th 
and 17th century, differentiation between eastern and western Europe based on it. For trade and industry and geographical and demographic expansion which it brought about became compulsory, Western Europe used the less labor, land, and other natural resources for needs. Thus, Eastern Europe had become granary of Western. Nevertheless, the opposite is also possible, according to Wallerstein. Here, small advantage determined which of the two alternatives would be dominant.

According to Wallerstein, the capitalist world-economy is a system that involves a hierarchical inequality of distribution based on the concentration of relatively monopolized and therefore high-profit production in certain limited zones, which there upon and thereby become the loci of the greatest accumulation of capital (Wallerstein, 1995, p. 26). In other words, within capitalist world-economy, unequal exchange is very important way of moving accumulated capital politically and economically weak regions to politically and economically strong regions: In order to understand the functioning of unequal exchange, following quoted text is remarkable:

Starting with any real differential in the market, occurring because of either the (temporary) scarcity of a complex production process, or artificial scarcities created Manu military, commodities moved between zones in such a way that the area with the less 'scarce' items to the other area at a price that incarnated more real input (cost) than an equally-priced item moving in the opposite direction. (Wallerstein, 1999, p. 31)

Thus, what really happened is that there was a transfer of the total profit being produced from one zone to another. Such a relationship is that of coreness-peripherality. It can be said that loosing zone is a "periphery" and the gaining zone is a "core" (Wallerstein, 1999, pp. 31-32).

This concentration or inequality enables the reinforcement of the state structures, which in turn seek to guarantee the survival of the relative monopolies. Nevertheless, because monopolies are inherently fragile, there has been a constant, discontinuous, and limited but significant of these centers of concentration all through the history of the modern world-system (Wallerstein, 1995, p. 26).

It means that all specialized region, which is called core, semi-periphery, and periphery, relocated over time in the capitalist world economy. For example, while Portugal was in core in the long 16th century, Holland seized it in the middle of the 16th century. Then, the core passed to London in the 17th century. United States of America emerged as the hegemonic power after World War II. Similarly, this relocation also applies to semi-periphery and periphery. For example, Flanders, east of Elbe and Hanseatic, cities were the "periphery" region in the 16th century and they relocated to semi-periphery towards the end of the 17th century.

When it is based on Wallerstein's historical and empirical-theoretical approach, it can be said that relocation of a state or region in the international division of labor, or shifting from periphery or semi-periphery to center/core depends on a number of factors. One of the most important factors is national intellectual capital. Hence, this study gives importance to the assets and capacity of the national intellectual capital.

\section{National Intellectual Capital}

Knowledge based economies will have the competitive advantage over traditional resource based economies in terms of wealth accumulation in future. Science, technology, innovation actors and their mutual interactions, intellectual capital accumulation oriented national policies will become most important driving forces for sustainable economic growth in global world. The most important input for production and supply of sophisticated goods and services is knowledge. Creation of knowledge and increasing the intellectual capital is 
only possible with national investment on human resourses development projects. Knowledge is only created by highly qualified human resources. Governments' efforts on generating productive knowledge sources will determine the fate of nations (Unesco, 2010, p. 2; Drucker, 1993).

John Kenneth Galbraith used the intellectual capital term on individual and organizational bases in 1969 in the "The Economist" journal. Later Steawart clearly defined intellectual capital term in an article titled as "Brainpower", published in Fortune 500 in the June 1991 (Stewart, 1991, p. 44). Scandia incorporation appointed Edvinsson as a world first chief knowledge executive (CKE) and he developed a navigator in order to measure organization's intangible resources. Scale was consisting indicators for customer relations, process, human resources and development and training activities (Edvinsson, 1997). Organization for Economic Co-operation and Development (OECD) first used intellectual capital term as a value creation process for organizations and nations in 1996 (OECD, 1996, p. 14).

Drucker (1993) also explained the concept of intellectual capital on in his work of post-capitalist society. Drucker draws the borders of the importance and arrival of a new society surrounded by knowledge resources. He explains the competitive environment for organizations and nations as follows:

The productivity of knowledge is going to be determining factor in the competitive position of a company, an industry, an entire country. No country, industry, or company has any 'natural' advantage or disadvantage. The only advantage it can posses is the ability to exploit universally available knowledge. The only thing that increasingly will matter in national as in international economics is management's performance in making productive. (Drucker, 1993, p. 176)

Later, Stewart developed his initial concept of intellectual capital and described sub-factors of intellectual capital as human capital, structural capital, and customer capital. Human capital is the organizational member's tacit knowledge that is usable for organizational goals. It also includes experiences, innovations, employees' behaviours and learning. Customer capital is a decisive sense that directs customers to use organization's goods or services. It is also mutual relationship and trust, customer satisfaction and loyalty. Structural capital is supportive infrastructure, organizational climate, culture, relations, processes and databases of the organization that enable human resources to function effectively (Stewart, 1997, p. 77-78, 163-165). Managerial accounting literature also explained intellectual capital as the difference between value of a firm's book value and its market value.

Foundations of intellectual capital can also be found in the strategic management literature (Ståhle \& Bounfour, 2008, p. 165). Resource based view of organizations considered the firm as a bundle of resources. Organizations should focus on heterogeneous and not perfectly mobile resources in order to gain sustained competitive advantage. Only valuable, rare, inimitable, and non-sustainable resources can assist the firm to produce competitive advantage and to gain above average returns (Wernerfelt, 1984, p. 172; Barney, 1991, p. 117). Only organizationally embedded, non-transferable firm-specific resources can help to improve the productivity of the firm (Makadok, 2001, p. 389).

Much of the academic literature on intellectual capital theory and its definitions, constructs, and measures stems from an accounting and financial perspective, focusing on the organizational level of analysis. Later, researchers turned their attention to national level of analysis. In this context, intellectual capital of a nation includes the gross total of internalized knowledge, experience, educational accumulation, skills, information infrastructure, information processing capability and creative power of individuals, institutions, cities and regions (Bontis, 2004, p. 31). It is a current and potential source for the creation of new products, services, and 
knowledge. Intellectual capital also includes intangible assets that refer to explicit, cognitive or emotional knowledge.

Literature on national intellectual capital supports the idea that NIC is an important driving force national competition (Bounfour \& Edvinsson, 2005; Ståhle, 2007; Edvinsson \& Lin, 2008). The countries with a competent intellectual capital will have a strong base to become a global power not only regionally but also internationally. Countries rich in intangible assets will be better in terms of national prosperity than those whose resources are limited to land, production tools, and workforce (Malhotra, 2003; World Bank, 1998). Intangible knowledge of individuals will lead to national economic growth, human resources development, and quality of life. NIC will cause supremacy and dominance of nation. It is difficult to mention about national sovereignty if the production technology and facilities are owned by other nations and the role of public is only supply of cheap work force.

The creation of knowledge is not an instantaneous happening but the result of a long-term exertion. Knowledge based inspiration comes to prepared minds. Creative knowledge is the result of intensive research and development effort. The important factors involved in the creation of knowledge are government research institutes, universities, and industrial R\&D centers. Government support policies for innovation actors, research facilitating legal and structural national infrastructure, macroeconomic stability, good governance, qualified research personnel, and interaction of innovation actors are necessary factors in knowledge creation (Dahlman, 2008, pp. 32-34). Knowledge can be created domestically or transferred from technology frontier nations. Foreign direct investment, licensing, technical assistance, and reverse engineering are the ways for technology transfer. Even if the knowledge is transferred successfully, adaptation, and implementation of it depends on the absorbtion capacity of a nation. The most important factor to increase absorption capacity is educated human resources and accumulated intellectual capital (see Table 1).

Table 1

The Four Pillar for a Knowledge Based Economy and Intellectual Capital Formation

(1) incentives and support programs for knowledge creation and entrepreneurship.

(2) Educated human resources that are capable of create and use knowledge.

(3) A dynamic information network that transfers knowledge to innovation actors.

(4) An effective interaction and collaboration between innovation actors like firms, research centers, universities, think tanks, consultants.

Note. Source: Adapted from Dahlman and Aubert (2001, p. xxv).

The competitive advantage has shifted from tangible assets to intangible assets. In the knowledge economy, not only the wealth of individuals, companies, and regions but also the entire nation's competitive power is dependent on the value and usefulness of knowledge. Knowledge is a resource that cannot deplete when used like resources. Its usage and application leads to innovation (Oprescu, 2012, p. 76).

This fact can be observed in the current policies and organization of highly successful international companies and developed nations. Research and development departments of global companies are mostly remained in their home countries but manufacturing facilities are moved to labor intensive and natural resource rich regions. Having many foreign invested factories and establishment of national infrastructure with foreign technology may have a meaning for a developing country, but without paying attention to development of intellectual capital, it is only a short-term survival strategy. 


\section{Country Profiles}

The economic development of major Asian countries and tiger economies during last 30 years is one of the inspiring success stories for under-developed and developing countries. Korea, Taiwan, China, and India all have started to their economic development as an agrarian country and reached at a point of high technology producer, information technologies exporter nations. They experienced a process of transition from a catch-up model of technological progress to a more creative approach. Especially, Korea and Taiwan have succeeded in industrialization and they are on the way of becoming a knowledge society. They are initiators and inventors of new technologies, producers of semiconductors, wireless telecommunication systems, software and hardware developers and electronic products. Industrialization process is started nearly same periods in all countries. India and China have a great source of human resources and effective governmental policies promoting knowledge creation. India, China, Korea, and Taiwan all have skilled research professionals, high tertiary technical enrollment rates, and high rates of IT products exports. They are aware of new opportunities to create commercially successful knowledge intensive products. Being among the world's most diverse nations, India and China are regional and global powers in terms of their political, historical, and cultural terms. Both of them have established ancient civilizations, and have strong historical and cultural relationships with neighboring countries. Turkey, Korea, India, and China are all members of G-20 counties. Turkey and Korea also both are members of OECD. Most importantly, they all started their economic development process by implementing statist policies first and later shifted to mixed or liberalized economic models since 1980s.

\section{India}

India is one of the world's oldest civilizations in the world and the main source of income for centuries was agriculture. Favourable climate and geography of the country provided a productive environment. Having occupied by British forces for long decades, financial and banking systems established, a single currency system used and capital market came into presence under British rule.

Five-year development plans aimed to increase quality and quantity of export items, establish new economic reforms and make country self-sufficient. Central planning, state investments on major industries and import substitution policies were characteristics of the development efforts after independence from British rule. Market liberalization was undertaken, foreign direct investments were allowed and public monopolies were privatized since 1980s). India had established itself as one of the world's fastest developing nations since 2000s (OECD, 2007).

Millions of entrepreneurs drive Indian capitalism. Indian business boomed after liberalization of the economy since the early 1990s and the innovative high tech companies spread over the country. India's R\&D intensity increased slightly but the share of the business enterprise sector in gross domestic expenditure on research and development has rose from $18 \%$ in 2003 to $28 \%$ in 2007 . The state is supporting high tech research oriented venture businesses in the areas of space technology, information technology, automotive, and pharmaceuticals. India has reach at a point which, about $14 \%$ of India's net domestic product is composed of knowledge intensive production. Data also shows that the majority of new companies are operating in the knowledge intensive areas. India has become the world's largest exporter of IT services since 2005 and exports of aerospace products have been increasing at a rate of $74 \%$ per year (UNESCO, 2010, pp. 363-364). The country is now one of the G-20 major economies and a member of BRICS. 


\section{China}

China's economic reforms and integration to world economy started after 1978. Economic was heavily depending on natural resources, petroleum, agricultural products, and cheap labor force. China became a major importer of raw materials, producer of consumer goods, and price competitive electronic products in 30 years. China is competing in world markets while preserving its communism oriented economic structure. Chinese economy is dominated by state owned holdings, however small and medium sized business has an important role in countries export. There are more than 10 million small and medium businesses (SMB) and they account $80 \%$ of jobs. They operate in industrial cluster in technoparks mostly (Batson \& Andrew, 2010). State owned companies invested capital-intensive heavy industries; construction of national infrastructure risky projects that beyond the capacity of SMB. However, small business is active on light industries, labor-intensive manufacturing, and IT sector. China becoming a high technology oriented goods producer like computers automobiles, contrary to the general image of low quality and price exporter. For example, ratio high technology exports in total manufactured goods exports increased from $18.9 \%$ in 2005 to $27.5 \%$ in 2011. Its per capita GDP had also grown from $\$ 153$ in 1982 to $\$ 5,430$ in 2011. China was the fastest growing nation with yearly growth rates changing from $9 \%$ to $11 \%$ since 1980 (Retrieved from http://databank.worldbank.org).

Chinese government was busy with agricultural reforms during 1980s. However foreign investors invited to country to establish joint ventures with domestic partners. Later banking sector liberalized, which is unusual to witness in a communist country. Many global companies decided to establish their production facilities and R\&D centers after China joined to World Trade Organization (WTO) in 2001. Today, China is the world's largest recipient of direct foreign investment.

One of the reasons for rapid industrialization is Chinese government's successful policies to develop highly qualified talent pool composed of engineers, scientist, and foreign educated researchers. For example, the number of engineers and scientist increased more than double to nearly two million in just eight years from 2000 (UNESCO, 2010, p. 379, pp. 389-391). In addition, the number of Doctor of Philosophy holders increased tenfold since 1990s (Ernest, 2011, p. 5). As of 2011, Chinese government offers more than 2,000 researches support program for universities, private, and government research laboratories (Springut, Schlaikjer, \& Chen, 2011, p. 37). Today, China has become one of the world's biggest sources for research and development personnel and has the largest human resources in world.

Government policies towards education, R\&D investment, and knowledge transfer through foreign direct investments and joint ventures seem to have begun pay off. China transformed itself from an agricultural country to a nation that doubling of its economy about seven years. If intellectual capital accumulation policies and high economic development rate continues, it may just be estimated that China will have biggest intellectual capital in the world.

\section{Taiwan}

Taiwan's economic growth was driven by import substitution policy, the expansion of labour intensive manufacturing export oriented government policies that was similar to industrialization of Korea. However, unlike Korea, economic drivers of country were the small and medium industries rather than big family holdings. Formation of trade triangle by United States, Japan, and Taiwan helped the rapid industrialization of nation. Rapid development attracted inward direct foreign investment from Japan and United States during 1970s and 1980s. 
Taiwan expelled from UN because of political pressure from China and politically isolated from rest of the World. However, political isolation did not stop it from enthusiastic export policies and even to invest to China, especially in the 1990s. Taiwan did not influenced by Asian financial crisis in 1997 due to its small-medium oriented industry structure and strong financial conditions in the country.

Taiwan's industries are transforming from mass production to IT oriented innovative products. Taiwan's potential in science and technology producing position is growing rapidly. It has qualified human resources and accumulated knowledge and experience advantages for the development of knowledge intensive industries. Taiwan industry is highly homogenized around small and medium companies, which plays a key role in absorbing and generating creative knowledge throughout country. According to the IMD's World Competitiveness Yearbook 2010, Taiwan has the world's third most entrepreneurial society.

Government's commitment to education established the foundations for the accumulation of intellectual capital Taiwan. This can be seen from the fact that $43.7 \%$ of the workforce has a college, university or higher education degree as of 2010. The number of researchers for every thousand employees in Taiwan is 10 , six person the same with Japan and slightly higher than nine, six person-year in the United States. It is also ranked 15th and 9th in the world for the number of papers published in the SCI and the EI Journals. Over the past few years, Taiwan government has effectively promoted the formation and development of industrial clusters and encouraged innovation. Taiwan's industrial cluster development ranks number one in the world in "World Competitiveness Report 2008-2009” (Taiwan Department of Investment Services, 2012).

\section{Korea}

Korea is well known for having established hi-tech industries, such as memory chips, telecommunication equipments, and other IT-related products. Having started as an agrarian country after Korean War, Korea transformed itself from a technology importer economy to technology frontier society. Korean economy developed an average rate of $8 \%$ and per capita income has increased from $\$ 87$ in 1962 to $\$ 20.759$ in 2011 (Retrieved from http://databank.worldbank.org).

Korean government mainly supported big Korean family holdings to invest on large-scale heavy and chemical industries since 1960s. They were active to invest in risky and expensive projects. At the initial stage, Korea relied heavily on imported manufacturing technology, such as turnkey plants. Korean industries produced "Original Equipment Manufacturing" products under foreign brand names. Alternative mechanisms for technological learning have been largely based on licensing, technical assistance, and reverse engineering. Technology importation and adoption was combined with low wages during 1980s. Above factors enabled Korea to compete in global market with relatively low priced products initially (Baek \& Jones, 2005, p. 30).

Since the early 1990s, government support polices for innovation actors, investment on national human resources, venture business boom after Asian financial crisis and enthusiastic investment on research and development by private sector have caused Korea to accumulate intellectual capital and reach the level of advanced countries. Especially 1997 Asian financial crisis have caused Korean government to focus on support policies for the establishment of IT oriented venture business and this helped to restructure of large business oriented innovation climate of country (Atay, 2012, p. 240).

Korean industries share on total R\&D investments was $71.8 \%$ while it was $28 \%$ for government. Tertiary school enrollment ratio of Korea has increased from $78.84 \%$ in 2000 to $103.1 \%$ in 2010 . Research and development expenditure as a ratio of GDP has also increased from $2.29 \%$ in 2000 to $3.36 \%$ in 2010 . Korea now ranks 15th in the world in terms of the number of SCI publications (Atay, 2011, pp. 8-10). 


\section{Research Methodology}

Different methodologies developed by researchers and institutions in order to measure national intellectual capital. Those tools and methodologies assist nations to analyze their competences and weakness and help to implement effective policies focused on growth of national innovation system. While there is no consensus reached, each research conducted on the goal of the analysis. International institutional organizations like World Bank and Organization for Economic Co-operation and Development (OECD) also developed methodologies to help nation's better development strategies.

OECD model focuses on inputs data rather than outputs when assessing NIC. For example, government investments on higher education and research and development infrastructure are sample items in assessment model. World banks comprehensive intellectual capital assessment methodology (Retrieved from www.worldbank.org/kam) consists of 148 structural and qualitative variables for 146 countries to measure their position on economic performance, economic regime, governance, innovation system, education, labor, and Information and Communication Technologies (ICT). There are four subgroups in the model. Economic performance, economic regime, and governance are grouped as economic and institutional regime $t$ sub group. Education and labor data are grouped as education and skills sub-group. Innovation system and ICT remained as separate sub-groups. Variables in each group are normalized on a scale from 0 (weakest) to 10 (strongest), and all 148 countries are ranked on an ordinal scale. The KAM therefore reports the relative performance of countries on the knowledge economy (see Figure 1). KAM is an on-line interactive tool that produces the Knowledge Economy Index (KEI). The KEI is based on a simple average of four sub-indexes, which represent the four pillars of the knowledge economy. The KEI summarizes overall assessment of each country's performance on 12 items. A KEI score that is close to 10 implies relatively good development of the four knowledge economy pillars as compared to other countries, while a score close to 0 indicates relatively poor development (World Bank, 2012, pp. 5-15).

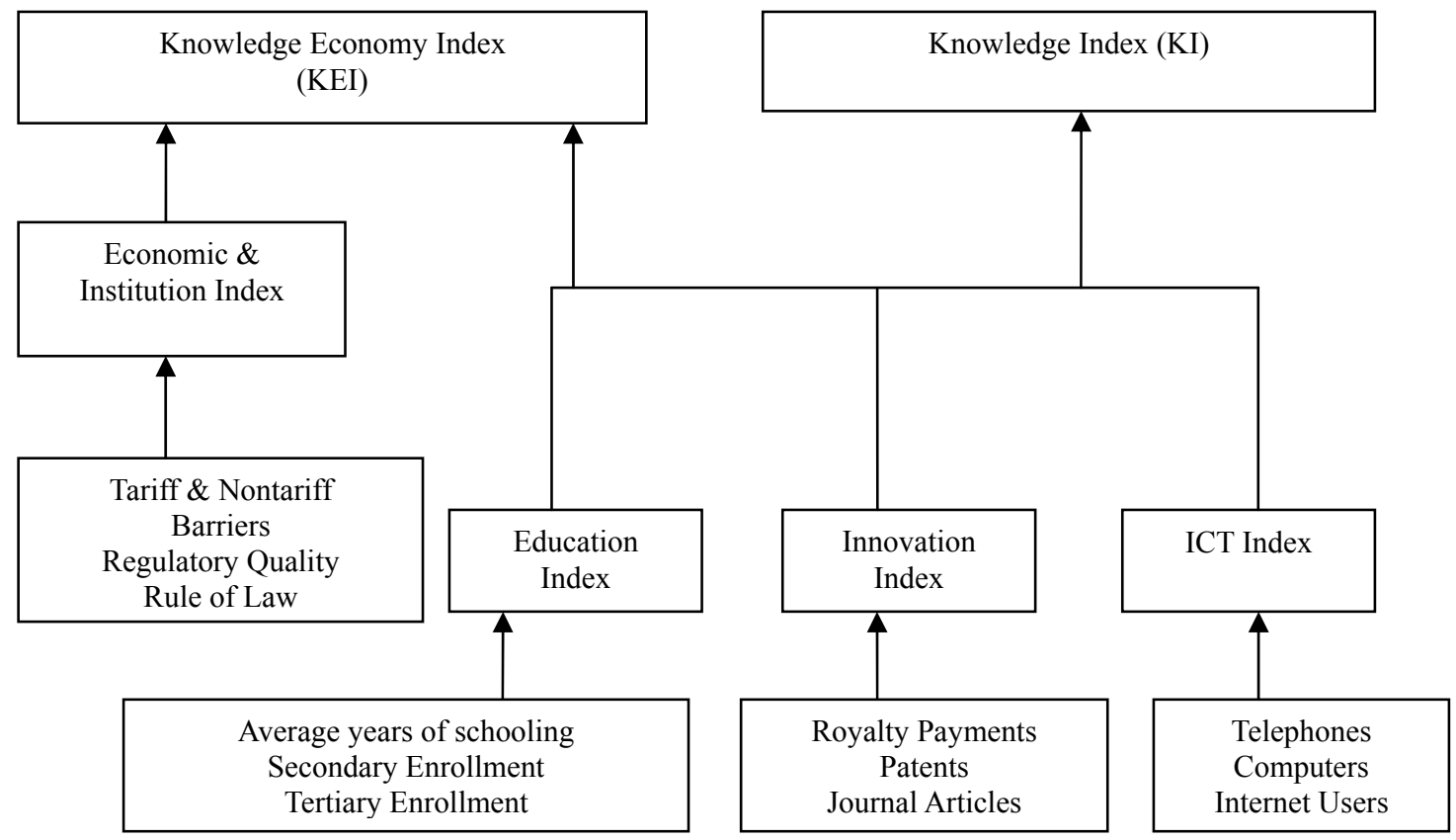

Figure 1. Knowledge indexes. Source: Retrieved from http://www.worldbank.org/kam. 
Custom scorecards section of KAM also allows any combination of the 148 variables to compare nations for different years. This research will use KEI index and four subgroups comparisons for a general understanding of relative positions of countries first. Then using custom scorecards different combinations of data will be used understand better relative status of nations.

\section{Results}

Table 2 shows the knowledge economy indicators, knowledge indicators, and sub-group performances of countries in 2012 and 1995 respectively. All values are re-calculated with the maximum value for each component as 10 in order to ensure unity in values. Table 3 shows the actual and normalized values for intellectual capital indicators used to calculate knowledge economy index and knowledge indexes.

Table 2

Knowledge Economy Indicators of Countries (Adjusted Values)

\begin{tabular}{|c|c|c|c|c|c|c|c|c|c|c|c|c|}
\hline \multirow{2}{*}{ Country } & \multicolumn{2}{|c|}{ KEI } & \multicolumn{2}{|c|}{ KI } & \multicolumn{2}{|c|}{ EIIR } & \multicolumn{2}{|c|}{ Innovation } & \multicolumn{2}{|c|}{ Education } & \multicolumn{2}{|c|}{ ICT } \\
\hline & 2012 & 1995 & 2012 & 1995 & 2012 & 1995 & 2102 & 1995 & 2012 & 1995 & 2012 & 1995 \\
\hline Taiwan & 8.77 & 8.36 & 9.1 & 8.55 & 7.77 & 7.8 & 9.38 & 9.21 & 8.87 & 8.11 & 9.06 & 8.33 \\
\hline Korea & 7.97 & 8.16 & 8.65 & 8.56 & 5.93 & 6.93 & 8.8 & 8.22 & 9.09 & 9.13 & 8.05 & 8.34 \\
\hline Turkey & 5.16 & 5.46 & 4.81 & 5.2 & 6.19 & 6.23 & 5.83 & 5.04 & 4.11 & 4 & 4.5 & 6.55 \\
\hline China & 4.37 & 3.99 & 4.57 & 4.17 & 3.79 & 3.46 & 5.99 & 4.07 & 3.93 & 3.68 & 3.79 & 4.77 \\
\hline India & 3.06 & 3.57 & 2.89 & 3.57 & 3.57 & 3.57 & 4.5 & 3.7 & 2.26 & 2.51 & 1.9 & 4.5 \\
\hline
\end{tabular}

Notes. KEI: Knowledge Economy Index; KI: Knowledge Index; EIIR: Economic and Institutional Regime; ICT: Information and Computer Technology. Source: Retrieved from http://www.worldbank.org/kam.

Table 3

Measures for Intellectual Capital (Real Values)

\begin{tabular}{|c|c|c|c|c|c|c|c|c|c|c|}
\hline \multirow{2}{*}{ Variable } & \multicolumn{2}{|l|}{ Turkey } & \multicolumn{2}{|l|}{ China } & \multicolumn{2}{|l|}{ India } & \multicolumn{2}{|l|}{ Korea } & \multicolumn{2}{|l|}{ Taiwan } \\
\hline & A & $\mathrm{N}$ & A & $\mathrm{N}$ & A & $\mathrm{N}$ & A & $\mathrm{N}$ & A & $\mathrm{N}$ \\
\hline Tariff \& Nontariff barriers & 85.4 & 7.06 & 71.6 & 2.66 & 64.2 & 1.12 & 70.8 & 2.45 & 86.2 & 7.41 \\
\hline Regulatory quality & 0.31 & 5.48 & -0.2 & 3.97 & -0.28 & 3.77 & 0.85 & 7.33 & 1.14 & 8.22 \\
\hline Rule of law & 0.12 & 6.03 & -0.35 & 4.73 & 0.05 & 5.82 & 1 & 8.01 & 0.93 & 7.67 \\
\hline $\begin{array}{l}\text { Royalty payments and receipts } \\
\text { (US\$/pop.) }\end{array}$ & 5.15 & 4.64 & 8.63 & 5.52 & 1.78 & 3.12 & 209.94 & 8.48 & $\mathrm{n} / \mathrm{a}$ & $\mathrm{n} / \mathrm{a}$ \\
\hline S\&E Journal Articles/Mil. people & 118.36 & 7.45 & 43.11 & 5.93 & 16.18 & 4.55 & 381.15 & 8.28 & 555.98 & 8.76 \\
\hline Patents Granted by USPTO/Mil. people & 0.35 & 5.41 & 1.05 & 6.51 & 0.51 & 5.82 & 151.18 & 9.66 & 322.58 & 10 \\
\hline Average years of schooling & 7.02 & 2.52 & 8.17 & 4.17 & 5.12 & 1.26 & 11.85 & 9.61 & 11.34 & 8.98 \\
\hline Gross secondary enrollment rate & 81.96 & 4.07 & 78.19 & 3.66 & 60.02 & 2.55 & 97.22 & 7.72 & 99.15 & 8.07 \\
\hline Gross tertiary enrollment rate & 38.37 & 5.74 & 24.53 & 3.97 & 13.48 & 2.98 & 100.02 & 9.93 & 83.77 & 9.57 \\
\hline Total telephones per 1,000 people & 1,060 & 4.62 & 800 & 3.24 & 480 & 1.86 & 1,380 & 6.28 & 1,800 & 9.1 \\
\hline Computers per 1,000 people & 60 & 3.22 & 60 & 3.22 & 30 & 1.99 & 580 & 8.63 & 840 & 9.73 \\
\hline Internet users per 1,000 people & 350 & 5.66 & 290 & 4.9 & 50 & 1.86 & 810 & 9.24 & 700 & 8.34 \\
\hline
\end{tabular}

Notes. A: Actual Value; N: Normalized Value. Source: Retrieved from http://www.worldbank.org/kam.

Turkey is in the third place in terms of KEI and KI indexes just after Taiwan and Korea. However, it is in a better place with respect to India and China. Turkey is in the fourth place just after China in terms of innovativeness. If sub-components of the index are investigated, it is in the third place in education and ICT usage criteria. However, there is a great difference in terms of real values when compared with Taiwan and Korea. For example, Turkey's actual values for science and engineering articles/Mil. people and patents 
granted by USPTO are lower than Taiwan and Korea that shows it will be difficult for Turkey to fill the gaps without highly investing science and technology. Turkey is in better condition with respect to India and China but its position is below Korea and Taiwan in all knowledge indexes.

\section{Detailed Data for More Precise Investigation}

Previous section used 12 criteria to calculate overall knowledge index and sub-indexes. However if the criteria, which are forming knowledge index, is increased results showed that Turkey's position is under China, India, Korea, and Taiwan in terms of innovativeness. In order to compare the relative positions of countries all real values of 24 criteria are re-calculated with a maximum value of 10 . Then a circle is drawn to see all countries position. Fullness of circle indicates a satisfactory level of knowledge economy or national intellectual capital. Smaller circles, which are close to center, indicate the inability of knowledge economy.

Turkey was in better condition with respect to India and China when 12 criteria are used. With the increased number of criteria, which are forming knowledge index, Turkey's position is near to the center of the circle with respect to China and India in terms of innovativeness. China is nearer to outer circle and in position with respect to India. India takes place between China and Turkey (see Figure 2). Turkey is nearer again to center with respect to Korea and Taiwan as expected. Turkey's fifth place in innovativeness indicates its weak innovation infrastructure compared with other nations (see Figure 3).

Figure 4 indicates that Turkey's information and communication technology infrastructure is weak with respect to India and China. Turkey's ICT circle is near to the center when compared with India and China. China nearer to outer circle and is in better position with respect to India. Results shows Turkey's insufficient investments especially on e-government services availability and ICT expenditures as percent of GDP.

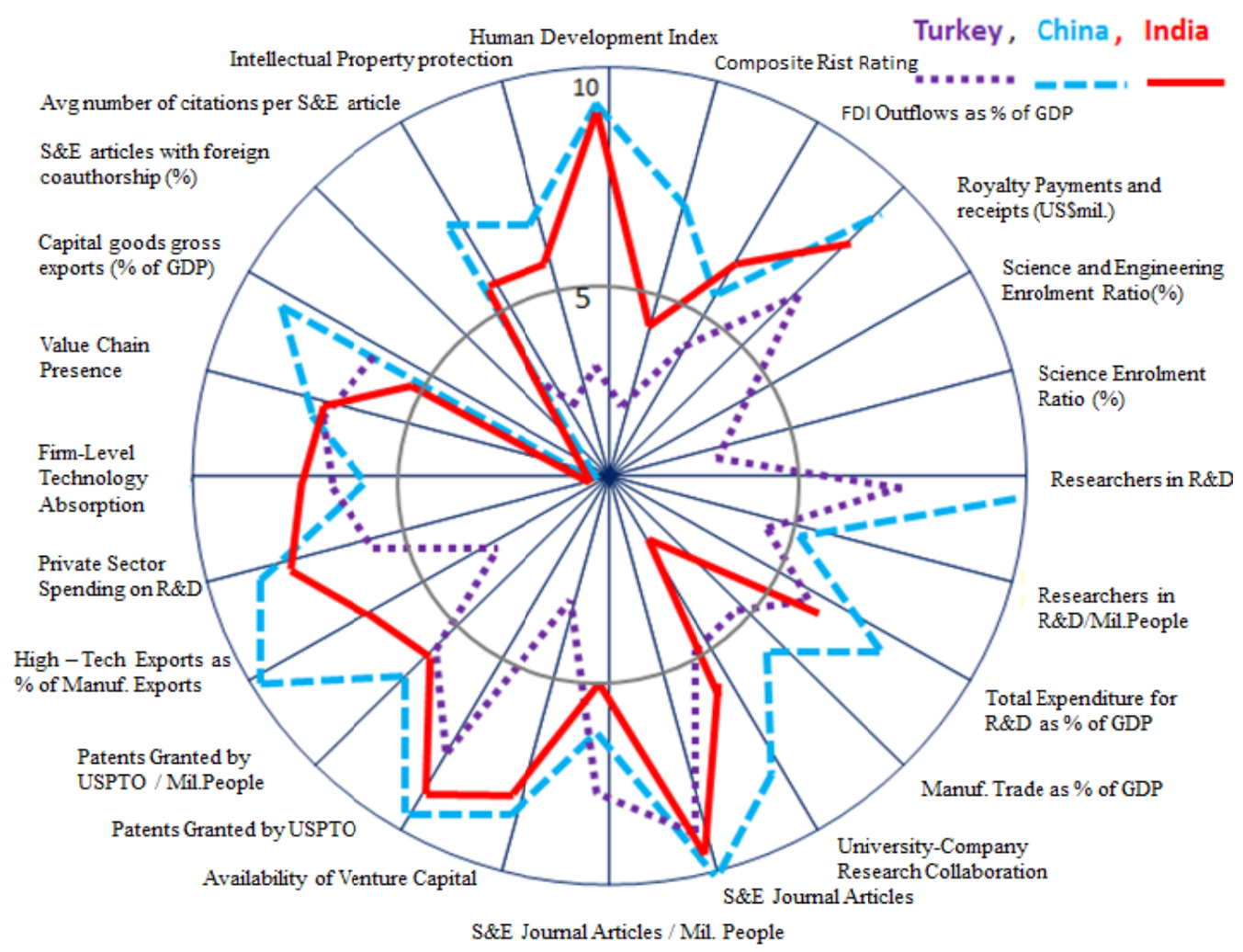

Figure 2. Turkey, China, India, innovation systems. 


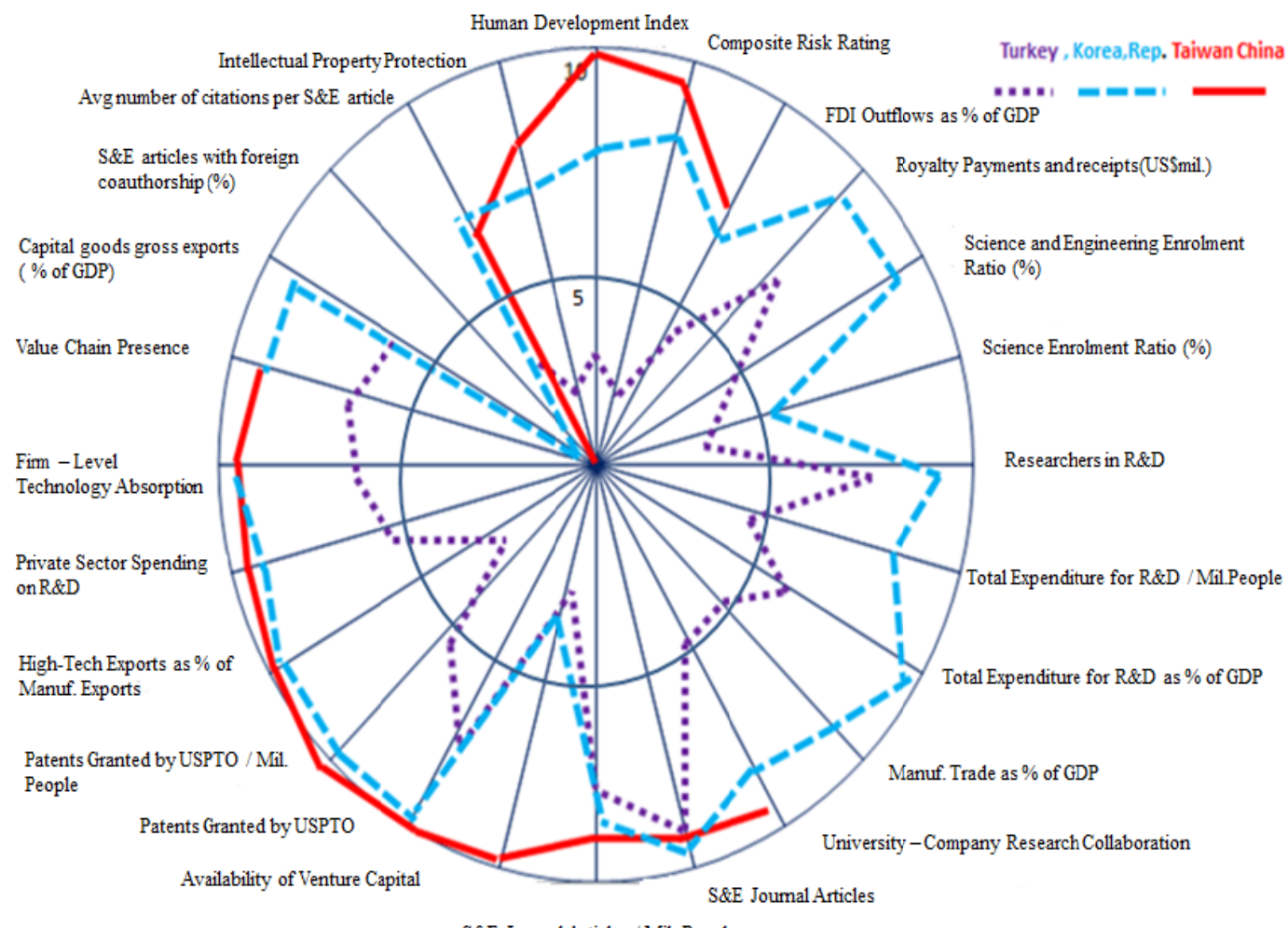

Figure 3. Turkey, Korea, and Taiwan innovation system.

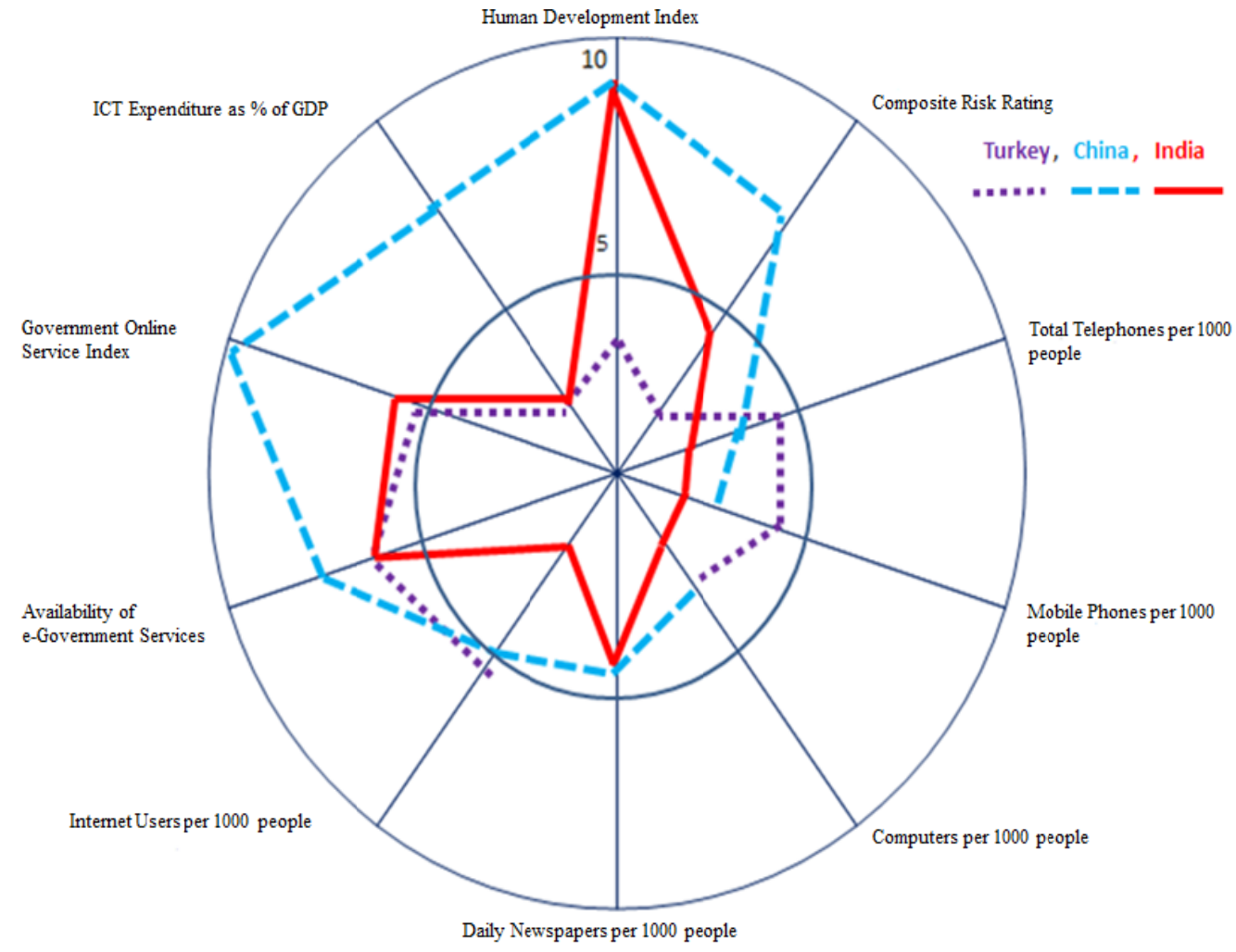

Figure 4. Turkey, China, India information and communication technologies. 
If diverse national intellectual forming criteria are used, it can be understood that Turkey has to invest much to develop its national intellectual capital with respect to China, India, Korea, and Taiwan. Table 4 shows that Turkey is in the fifth place in 11 criteria and is in the fourth place in four criteria. Especially in terms of university-company research collaboration, patents granted by USPTO, and high-tech exports as percent of manufacturing exports criteria Turkey is behind China.

Table 3

Some Selected Individual Indicators of National Intellectual Capital

\begin{tabular}{|c|c|c|c|c|c|c|}
\hline Variable & Turkey & Korea & Taiwan & China & India & $\begin{array}{l}\text { Turkey's } \\
\text { rank in } \\
\text { others }\end{array}$ \\
\hline Human Development Index, 2010 & 0.58 & 0.81 & 0.94 & 0.88 & 0.87 & 5 \\
\hline Composite Risk Rating & 63.07 & 79.96 & 84.4 & 75.49 & 68.28 & 5 \\
\hline Total Expenditure for R\&D as $\%$ of GDP & 0.73 & 3.36 & $\mathrm{n} / \mathrm{a}$ & 1.47 & 0.76 & 4 \\
\hline University-Company Research Collaboration (1-7), 2010 & 3.4 & 4.7 & 5.2 & 4.6 & 3.7 & 5 \\
\hline S\&E Journal Articles/Mil. People, 2007 & 118.36 & 381.15 & 555.98 & 43.11 & 16.18 & 3 \\
\hline Patents Granted by USPTO/Mil. People, avg 2005-2009 & 0.35 & 151.18 & 322.58 & 1.05 & 0.51 & 5 \\
\hline High-Tech Exports as \% of Manuf. Exports, 2009 & 2 & 32 & 46 & 31 & 9 & 5 \\
\hline Private Sector Spending on R\&D (1-7), 2010 & 3 & 4.7 & 5 & 4.1 & 3.6 & 5 \\
\hline Average Years of Schooling, 2010 & 7.02 & 11.85 & 11.34 & 8.17 & 5.12 & 4 \\
\hline Unemployment Rate, Total ( $\%$ of labor force), 2005-2009 & 11.22 & 3.42 & 4.38 & 4.1 & 4.4 & 5 \\
\hline Extent of Staff Training (1-7), 2010 & 3.7 & 4.4 & 4.7 & 4.1 & 4.1 & 5 \\
\hline Brain Drain (1-7), 2010 & 3 & 4,8 & 4,7 & 4,3 & 4,3 & 5 \\
\hline Computers per 1,000 People, 2008 & 60 & 580 & 840 & 60 & 30 & 4 \\
\hline Availability of e-Government Services (1-7), 2008 & 4.11 & 5.53 & 5.32 & 4.71 & 4.21 & 5 \\
\hline
\end{tabular}

Note. Source: Retrieved from http://www.worldbank.org/kam.

\section{Conclusions}

This study aimed to inquire the economic and political target of Turkey: Turkey's projection for the year 2023 have been adopted as including in the world's most advanced 10 countries in this date which is corresponds to 100th anniversary of the proclamation of the Republic. In our opinion, the meaning of the 2023 projection and Turkey's economic development efforts and reforms, which have continued for the last 30 years, is an attempt to pass from a semi-peripheral political unit to the central (core) states in the international division of labor of the capitalist world-economy. In this sense, the basic claim of this study is that although Turkey achieved political stability, realized economic growth rates, put into practice socio-economic, and administrative bureaucratic reforms, all this will not be enough for Turkey to carry from the semi-periphery to the centre in the short and medium term.

In this study, two-dimensional discussion is realized in order to support the idea. First, it was explained why the mentioned efforts positive statistical data will not be enough for Turkey's 2023 vision. For this purpose, it is necessary to make an inquiry on logic of the background of the functioning of the capitalist world-economy. By relying on the views of Wallerstein, it is emphasized that the capitalist world-economy creates - and is based on - both as a geographically and technologically a hierarchical division of labor. This division of labor can be called as the central government(s) and peripheral and semi-peripheral areas. The basic principle that distinguishes between central, periphery, and semi-periphery is skill in using relative advantage and superiority on production and, of course, marketing of goods that are more profitable and less "scarce" than 
other areas. This advantage and specialization can be raw materials, as well as products and services that are required advanced technology, specialization, and high organization.

This is exactly the second point of this discussion. The factor which will provide an advantage to a region or state compared with other regions in the 21 st century is national intellectual capital. It can be said that the realizing their transition of states or regions from the semi-periphery to the center in the international division of labor is possible by increasing the national intellectual capital and its ability level.

In this context, our comparative investigation showed that Turkey is in the third place in terms of KEI and $\mathrm{KI}$ indexes, just after Taiwan and Korea between five countries. However, it is in a good place with respect to India and China. Turkey is in the fifth place in terms of innovativeness and in the third place in education and ICT usage criteria. However, there is a great difference in terms of real values when compared with Taiwan and Korea.

If the national intellectual forming criteria added more to assessment method, it can be understood that Turkey has to invest much to develop its intellectual capital with respect to other nations. Because Turkey is in the fifth place in 18 criteria, is in the fourth place in 14 criteria and is in the third place in nine criteria among five nations.

As a result, this comparative investigation shows that, Turkey has not been ready yet for achieving the "2023 Project". This determination or point not only the intellectual position but also mainstay it can be made a suggestion.

It should be accomplished the transition from a catch-up model of technological progress to a more creative and intellectual capital accumulative approach. Intellectual capital of a nation is the invisible wealth of a country. For this purpose, a range of policies should be implemented:

For example, Turkey should increase interaction efforts between business, government, and academic R\&D activities in order to increase the output of codified knowledge in the form of patents and publications. Turkey should immediately develop long-term policies on basic and applied scientific research and establish a competitive support system for universities, innovative venture companies, and industrial research institutions. In addition, Turkey should improve the quality of education at the primary and secondary level to better prepare students to participate in a knowledge-based economy. In addition, Turkey should restructure the tertiary education sector through competition by disclosing performance information for each university and develop a transparent mechanism, such as an independent national body with clearly defined criteria and standards, to assess the quality of educational services. Furthermore, Turkey should develop lifelong learning programs to meet the learning needs of all, both within and outside the school system, including using distance-learning technologies to expand access to and the quality of formal education and lifelong training programs. The application of ICT to government, business, and overall public life can provide significant push to knowledge creation and strengthen intellectual infrastructure.

\section{References}

Acar, O., \& Çağlar, E. (2012). Yeni Teşvik Paketi Üzerine Bir Değerlendirme. Retrieved from http://www.tepav.org.tr/upload /files/1334047274-0.Yeni_Tesvik_Paketi_Uzerine_Bir_Degerlendirme.pdf

Atay, E. (2012). From crisis to innovation: The case of South Korea. Dumlupinar University Journal of Social Sciences, 32(2), 239-254.

Atay, E. (2012). South Korea's innovation strategy. Proceedings from EBES, The Eurasia Business and Economics Society, İstanbul: Turkey. 
Baek, Y., \& Jones, R. S. (2005). Sustaining high growth through innovation: Reforming the R\&D and education systems in Korea, OECD Economics Department Working Papers, 470, OECD Publishing.

Barney, J. B. (1991). Firm resources and sustained competitive advantage. Journal of Management, 17(1), 99-120.

Batson, A. (2010). Rising wages rattle China's small manufacturers. Retrieved from http://0nline.wsj.com/article/SB100001424052748703314904575399111408113090.HTML

Bekiroğlu, C. (2010). Türkiye de İşsizlik Sorununun Çözümlenmesinde Uygulanan Ekonomi Politikalarının Analizi (Unpublished Master Thesis, Kadir Has Üniversitesi, SosyalBilimlerEnstitüsü, İstanbul).

Bontis, N. (2004). National intellectual capital index: A United Nations initiative for the Arab region. Journal of Intellectual Capital, 5(1), 13-39.

Bounfour, A., \& Edvinsson, L. (2005). IC for communities, nations, regions, cities, and other communities. Boston: Butterworth-Heinemann.

Braudel, F. (1977). Afterthoughts on material civilization and capitalism (P. M. Ranum, Trans.). Baltimore: The Johns Hopkins University Press.

Çalış, Ş. (2011). 2000'li Yıllarda Türkiye'de İstihdam Politikaları. In Y. Alpaydın \& H. Tunalı (Eds.), 2000 Sonrası Türkiye İktisadının Değişimi (pp. 307-322). İstanbul: İstanbul TicaretOdası Yay.

Çetintaş, H., \& Vergil, H. (2003).Türkiye'de Kayıtdış1 Ekonominin Tahmini. Doğuş Üniversitesi Dergisi, 4(1), 15-30.

Dahlman, C. (2008). Technology, globalisation, and international competitiveness: Challenges for developing countries. In D. O’Connor, \& M. Kjöllerström (Eds.), Industrial development for the 21st century: Sustainable development perspectives ( $\mathrm{pp}$. 29-84). New York: United Nations.

Dahlman, C. J., \& Aubert, J. E. (2001). China and the knowledge economy: Seizing the 21st century: Overview. Washington, D.C.: World Bank.

Dinç, C. (2011). 2000’li Yıllarda Türk Sosyal Devletindeki Değişimler. In Y. Alpaydın, \& H. Tunalı (Eds.), 2000 Sonrası Türkiye İktisadının Değişimi (pp. 323-357). İstanbul: İstanbul TicaretOdası Yay.

Drucker, P. F. (1993). The post capitalist society. U.K.: Butterworth-Heinemann.

Edvinsson, L. (1997). Developing intellectual capital at Skandia. Long Range Planning, 30(3), 366-373.

Edvinsson, L., \& Lin, C. (2008). National intellectual capital: Comparison of the Nordic countries. Journal of Intellectual Capital, 9(4), 525-545.

Ernst, D. (2011). China's innovation policy is a wake-up call for America. Asia Pacific Issues, 100, 1-12.

Eser, B. Y., \& Terzi, H. (2003). Türkiye'de İşsizlik Sorunuve Avrupa İstihdam Stratejisi. Erciyes Üniversitesi İktisadive İdari Bilimler Fakültesi Dergisi, 30, 229-250.

Kartal, F. (2011). Türkiye'de Enflasyon Hedeflemesi Stratejisive Para Politikasının Görünümü. Maliye Finans Yazıları Dergisi, 25(9), 77-100.

Kaya, S. S., Akiş, E., \& Çağlar, Ü. (2011). Türkiye'de 2000 Sonrası Uygulanan Para ve Kur Politikaları. In Y. Alpaydın, \& H. Tunalı (Eds.), 2000 Sonrası Türkiye İktisadının Değişimi (pp. 69-103). İstanbul: İstanbul TicaretOdası Yay.

Makadok, R. (2001). Toward a synthesis of the resource-based view and dynamic-capability views of rent creation. Strategic Management Journal, 22(5), 387-401.

Malhotra, Y. (2003). Measuring national knowledge assets of a nation: Knowledge systems for development, report of the ad hoc expert group meeting on knowledge systems for development, department of economic and social affairs division for public administration and development management. New York: United Nations. Retrieved from http://unpan1.un.org/intradoc/groups/public/documents/un/unpan011601.pdf masterthesis, Kadir Has Üniversitesi, SosyalBilimlerEnstitüsü, İstanbul).

$\begin{array}{llllll}\text { Nation } & \text { Master } & \text { China } & \text { Economic } & \text { Indicators. } & \text { (2012). }\end{array}$ http://www.nationmaster.com/red/country/ch-china/eco-economy\&all=1

OECD. (1996). The knowledge-based economy. Paris: OECD.

OECD. (2007). Economic survey of India 2007: Policy brief. Retrieved from http://www.oecd.org/economy/economicsurveysandcountrysurveillance/39452196.pdf

Oprescu, R. (2012). Challenges for the knowledge society. Management \& Marketing, 7(1), 73-88.

Springut, M., Schlaikjer, S., \& Chen, D. (2011). China's program for science and technology modernization: Implications for American competitiveness prepared for the U.S.-China economic and security review commission. Arlington: Centra Technology, Inc.. 
Ståhle, P. (2006). Five steps for Finland's future: A high-level round table initiated by the new club of Paris held in Helsinki. Helsinki: Tekes.

Ståhle, P., \& Bounfour, A. (2008). Understanding dynamics of intellectual capital of nations. Journal of Intellectual Capital, 9(2), 164-177.

Stewart, T. A. (1991). Brainpower: Intellectual capital is becoming corporate America's most valuable asset and can be its sharpest competitive weapon. Fortune, Spring Issue, 44-57.

Stewart, T. A. (1997). Intellectual Capital: The New Wealth of Organizations, Doubleday New York, N.Y.: USA.

Taiwan Department of Investment Services. (2012). Superior innovation capability. Retrieved from http: //investtaiwan.nat.gov.tw/matter/show_eng.jsp?ID=412\&MID=1

Tomé, E. (2004). Intellectual capital, social policy, economic development and the world evolution. Journal of Intellectual Capital, 5(4), 648-665.

UNESCO. (2010). Science report 2010: The status of science around the world. Global: UNESCO.

Wallerstein, I. (1974a). The modern world-system: Capitalist agriculture and the origins of the European world-economy in the sixteenth century. New York: Academic Press.

Wallerstein, I. (1974b). The rise and future demise of the world capitalist system: Concepts for comparative analysis. Comparative Studies in Society and History, 16(4), 387-415.

Wallerstein, I. (1993). The world-system after the cold war. Journal of Peace Research, 30(1), 1-6.

Wallerstein, I. (1995). After liberalism. New York: The New Press.

Wallerstein, I. (1999). Historical capitalism with capitalist civilization. London: Verso.

Wallerstein, I. (2004). World-system analysis: An introduction. London: Duke University Press.

Wernerfelt, B. (1984). The resource-based view of the firm. Strategic Management Journal, 5(2), 171-180.

World Bank Knowledge Assessment Methodology. (2012). Retrieved from http://www.worldbank.org/kam

World Bank. (1998). World development report: Knowledge for development. Oxford: Oxford University Press.

World Bank. (2012). Measuring knowledge in the world's economies: Knowledge assessment methodology and knowledge economy index, 56161. Global: World Bank. Retrieved from http://siteresources.worldbank.org/INTUNIKAM/Resources/KAMbooklet.pdf 